\title{
Monoclonal Gammopathy
}

National Cancer Institute

\section{Source}

National Cancer Institute. Monoclonal Gammopathy. NCI Thesaurus. Code C35548.

An abnormal laboratory test result indicating the presence of monoclonal

immunog lobulins in the blood or urine. 